\title{
KAJIAN STRUKTUR CERITA RAKYAT DI KABUPATEN CIANJUR
}

\author{
Ruswendi Permana \\ Departemen Pendidikan Bahasa Daerah FPBS UPI \\ Posel: ruswendi.permana@upi.edu
}

\begin{abstract}
Abstrak
Tujuan dari penelitian ini adalah untuk menggambarkan keberadaan cerita rakyat di Wilayah Kabupaten Cianjur. Cerita rakyat yang ada di Kabupaten Cianjur memiliki ragam jenis yang berbeda. Berdasarkan pada isi tersebut cerita rakyat itu ada yang tergolong mite, fabel, parabel, dan legenda. Keempat jenis ragam cerita ini masih cukup dikenal di dalam kehidupan masyarakat, baik anak-anak, remaja maupun dewasa. Dengan demikian jelaslah bahwa cerita rakyat, khususnya legenda merupakan materi yang dapat menciptakan berkembangnya cerita rakyat yang bercorak baru dan selaras dengan perkembangan zaman. Fungsi cerita rakyat khususnya legenda di Kabupaten Cianjur memiliki fungsi sebagai berikut: (1) Sebagai alat untuk mewariskan tata cara hidup, dat istiadat, dan kebiasaan, (2) Sebagai alat untuk mewariskan kepercayaan, (3) Sebagai alat untuk menyampaikan pendidikan, baik pendidikan lahir maupun batin, (4) Sebagai cara untuk meyampaikan asalusul terjadinya hal-hal yang mengandung sejarah, (5) Sebagai alat hiburan, mengisi waktu senggang. Penutur cerita rakyat cukup beragam, baik umur, jenis kelamin maupun pekerjaan. Dilihat dari jenis kelamin penutur pria lebih banyak jika dibandingkan dengan wanita, umur penutur rata-rata berkisar dari 36-80 tahun. Adapun pekerjaan umumnya sebagai pendidik (guru). Para penutur umumnya orang-orang yang dianggap mengenal dengan baik daerahnya masing-masing dan dianggap cukup mampu untuk memberikan informasi tentang daerahnya. Para penutur ini umumnya bersuku Sunda.
\end{abstract}

Kata Kunci: kajian struktur, cerita rakyat

\section{THE STUDY OF THE FOLKLORE STRUCTURE IN CIANJUR REGENCY}

\begin{abstract}
The aim of this study was to describe the presence of folklore in Cianjur Regency. The folklore in Cianjur Regency has a variety of types. Based on the contents, the folklore covers myth, fable, parable, and legend. The four types are still well known in public life, whether children, adolescents and adults. Thus, it is clear that the folklore, in particular the legend, is the material that can create a new development of folklore characters and in tune with the times. The functions of folklore, in particular legend, in Cianjur cover (1) as a means to pass on the way of life, traditions, and customs; (2) as a means to pass on trust; (3) as a means to deliver inner and outer education; (4) as a way to present the origin of the things that contains history; and (5) as a means of entertainment, to fill spare time. The folklore tellers are quite diverse in age, gender, or occupation. Mostly, they are men. The average age of the tellers ranged from 36-80 years old. Generally, they are educators (teachers). The tellers are commonly the people who are considered to know well their regions and are considered capable enough to provide information about the area. The tellers are generally the Sundanese.
\end{abstract}

Keywords: the structure study, folklore. 


\section{PENDAHULUAN}

Masyarakat Jawa Barat memiliki keragaman budaya bernilai luhur yang hakikatnya merupakan hasil cipta, karya, dan karsa masyarakat sebelumnya. Peninggalan leluhur tersebut sarat dengan nilai, norma, serta gagasan-gagasan pikiran masayarakat yang bersangkutan. Kristalisasi dari kandungan nilainilai tersebut mereka tuangkan dalam bentuk yang berbeda-beda. Diantaranya, dituangkan dalam bentuk lisan, seperti cerita rakyat, baik jenis mite, legenda, dongeng maupun jenis lainnya. Cerita rakyat (tale), yaitu cerita rakyat yang disebarluaskan dan diwariskan secara lisan dan digolongkan menjadi tiga kelompok besar yaitu mite, legenda, dan dongeng. Kemudian jenis cerita rakyat ini bisa diklasifikasikan menjadi menjadi cerita rakyat yaitu, mite, legenda, dongeng, fabel, dan cerita jenaka. Mite adalah jenis cerita rakyat yang tokoh-tokohnya dianggap keramat; legenda adalah jenis cerita yang tokoh-tokohnya dianggap pernah ada dan berkaitan dengan kejadian alam yang dianggap luar biasa; fabel adalah cerita tentang binatang yan dianggap seperti manusia. Biasanya cerita ini mengandung unsur pendidikan bagi anakanak dan petuah-petuah mengenai hal baik dan buruk; sedangkan cerita jenaka biasanya mengandung unsur sindiran, kritik social, dan mengandung unsur pendidikan.

Cermin rakyat mempunyai fungsi penting dalam kehidupan, sebab dapat mencerminkan kehidupan masyarakat serta dapat digunakan untuk mengenal cirri-ciri khas kebudayaan dan untuk menanmkan rasa cinta terhadap kebudayaan sendiri. Namun sampai saat ini cerita rakyat atau cerita rakyat Sunda masih banyak yang belum dikumpulkan atau diteliti. Bagian-bagian cerita rakyat Sunda ada yang hilang karena jumlah pendukungnya yang berusia lanjut banyak yang sudah meninggal, sedangkan proses pewarisan cerita kepada generasi yang lebih muda tidak berjalan dengan baik.

Kegiatan penelitian cerita rakyat ini secara umum bertujuan untuk mengenali serta memperkaya khasanah budaya Kabupaten Cianjur khususnya, dan Jawa Barat pada umumnya. Adapun tujuan khusus lebih diarahkan pada pengumpulan cerita rakyat di Kabupaten Cianjur melalui pendataan dan perekaman, menyalin rekaman dalam bentuk tertulis, kemudian menerjemahkannya ke dalam bahasa Indonesia, dan mengetahui struktur cerita rakyat yang berhubungan dengan tema, plot, amanat, serta tokoh cerita.

Penelitian ini menerapkan prinsip-prinsip strukturalisme dalam pengkajian cerita rakyat. Untuk memperjelas gagsasan itu, berikut ini akan dibicarakan konsep-konsep yang berkenaan dengan teknik penelitian.

Jean Peaget (dalam Hawkes, 1978) dalam bukunya Structuralisme, seperti yang dikuktip oleh dalam bukunya Structuralism and Semiotics menyatakan bahwa pengertian struktur dapat dipahami lewat susunan keseluruhan, meliputi tiga gagasan fundamental yang mencakup ide keutuhan (the idea of wholeness), Ide transformasi (the idea of transformation), dan ide adanya aturan sendiri (the idea of self-regulation).

Yang dimaksud dengan keutuhan adalah adanya koherensi internal. Susunan dari suatu keutuhan lengkap dengan sendirinya, dan bukan merupakan gabungan yang dibentuk oleh elemen-elemen independent yang berbeda-beda. Bagian-bagian unsurnya membentuk seperangkat aturan intrinsic yang menentukan hakikatnya. Aturan intrinsic ini lebih banyak menjadikan bagian-gabian unsur memiliki sifatsifat keseluruhan struktur daripada sifat-sifat individual yang dimilikinya diluar struktur. Demikianlah sebuah struktur sangat berbeda dari suatu himpunan (agregat) karena bagianbagian unsurnya tidak memiliki eksistensi yang independent di luar struktur.

Struktur merupakan suatu konstruksi konkrit yang bagian-bagiannya sanggup mengubah dimensi dan kualitasnya serta tidak ada bagian dari keseluruhan yang dapat dihilangkan tanpa merusak keutuhannya. Semua bagian dari suatu struktur secara potensial efektif. Fungsi dari aneka ragam bagian struktur tergantung pada konteks dan perangkap struktur (Fokkema dan Kunne-Ibsch, 1977). Dengan acuan gagasan struktur sebagaimana telah diterangkan sebelumnya penyikapan cerita rakyat sebagai suatu struktur yang berimplikasi pada pengakuan bahwa cerita rakyat memiliki aturan otonom yang karakteristik.

\section{METODE}

Metode yang digunakan dalam penelitian ini adalah metode deskriptif. Langkah pertama yang dilakukan adalah studi pustaka, hal ini untuk mengetahui konsep-konsep atau teori- 
teori tentang cerita rakyat sebagai dasar pengetahuan bagi peneliti. Selanjutnya, dengan menerapkan teori serta memperhatikan kenyataan di lapangn, dipersiapkan instrument wawancara sebagai pedoman di lapangan dalam mengumpulkan informasi dari tokoh masyarakat dan orang-orang yang dianggap mengetahui tentang cerita rakyat di daerahnya.

\section{HASIL DAN PEMBAHASAN}

\section{Kedudukan Cerita Rakyat di Kabupaten Cianjur}

Cerita rakyat merupakan titik awal dari perkembangan adanya sastra Sunda secara tertulis. Cerita rakyat dapat digunakan untuk memperkaya khasanah kesusasteraan Sunda bahkan Indonesia. Cerita rakyat dapat mengisi kekosongan yang terjadi bila para pengarang membutuhkan fariasi, atau dikatakan sebagai penunjang sastra tertulis.

Dilihat dari kenyataannya, cerita rakyat tidak terlepas dari kehidupan masyarakat, dan cerita rakyat itu seperti juga sastra tertulis yang merupakan pancaran dari masyarakat pemeluknya.

Dengan uraian diatas dapatlah disimpulkan bahwa cerita rakyat di kabupaten Cianjur itu memiliki fungsi sebagai berikut: (1) Sebagai alat untuk mewariskan tat cara hidup, adat istiadat dan kebiasaan sehari-hari, (2) Sebagai alat untuk mewariskan kepercayaan, (3) Sebagai alat untuk menyampaikan pendidikan, baik pendidikan secara lahir (berupa ilmu pengetahuan) maupun pendidikan batin, moral, etika, dan agama, (3) Sebagai cara untuk menyampaikan asal-usul kejadian dan hal-hal yang mengandung berita atau sejarah, (4) Sebagai alat untuk hiburan, mengisi waktu senggang, baik waktu yang terluang diantara pekerjaan penduduk sehari-hari, maupun waktu yang sengaja disediakan dalam acara tertentu.

\section{Penutur Cerita dan Kesempatan Bercerita}

Dari hasil pendataan dan wawancara di lapangan yang dilakukan melalui perekaman di daerah tempat penutur sendiri, bahwa para penutur cerita umumnya berasal dan dibesarkan di daerah masing-masing sehingga mereka dapat lebih mengenal dengan baik daerahnya beserta cerita tersebut.

Cerita lisan yang dikumpulkan adalah cerita yang disampaikan oleh penutur yang tinggal di kecamatan-kecamatan yang ada di
Kabupaten Cianjur. Perekaman cerita dilakukan tidak jauh dari tempat-tempat kejadian yang terkandung dari ceritanya, bahkan mencoba membuktikan atau melihat peninggalanpeninggalan ceritanya. Hanya sebagian kecil saja cerita yang direkam bukan di dekat tempat kejadian.

Semua penutur umumnya orang-orang yang dianggap mengenal dengan baik dearah di wilayahnya masing-masing dan mampu memberikan informasi tentang daerahdaerahnya. Semua penutur merupakan asli orang Kabupaten Cianjur yang sehari-hari menggunakan bahasa Sunda.

\section{Analisis Struktur Cerita Rakyat 1. Sasakala Talaga Warna (Kec. Pacet) Jalan Cerita}

Alur cerita Sasakala Talaga Warna dapat diskemakan sebagai berikut: Maharaja Prambonan mempunyai seorang putri yang sangat cantik, Dewi Mayangsari. Banyak rajaraja yang hendak menjadikannya sebagai prameswari. Dewi Mayangsari selalu menolak. Datang lamaran dari Raden Layung Kumendung. Dewi Mayangsari juga menolak. Kemudian datang pula lamaran dari Prabu Manyir, juga ditolak. Terjadi pertarungan antara utusan Layung Kumendung dengan utusan Prabu Manyir. Raja Prambonan mengadakan sayembara (pemenangnya berhak mempersunting Dewi Mayangsari). Pemenangnya Layung Kumendung. Dewi Mayang sari mengajukan persyaratan tambahan (sebakul permata). Layung Kumendung dapat memenuhinya. Saat pernikahan berlangsung, Dewi Mayangsari menghias setiap helai rambutnya dengan permata. Raja melarangnya. Dewi Mayangsari marah dan melempari raja dengan bakul tempat permata. Raja murka. Dewi Centringmanik mengutuknya. Layung Kumendung, Dewi Centringmanik, dan Gjah Panambur kembali ke pertapaan. Kerajaan Prambonan menjadi telaga.

Layung Kumendung dapat melewati beberapa rintangan dalam hidupnya. Peristiwa yang dialaminya adalah sebagai berikut : Layung Kumendung merindukan Dewi Mayangsari - Mahawiku Dewi Centringmanik bingung karena Layung Kumendung tidak sederajat dengan Dewi Mayangsari - Dewi Centringmanik maminta bantuan Eyang Uja Eyang Uja memohon pertolongan Patih Gajah 
Mada Panambur dari kerajaan Batu Ngampar Gajah Panambur menyampaikan lamaran Layung Kumendung - Lamaran ditolak - Gajah Panambur bertarung dengan Patih Aria menang - Layung Kumendung diberi syarat tambahan (sebakul permata) - Layung Kumendung berhasil memenuhinya - Dewi Mayangsari menghias tiap helai rambutnya dengan permata - Raja Prambonan murka - Dewi Centringmanik mengutuknya - Layung Kumendung, Dewi Centringmanik, dan Gajah Panambur kembali ke pertapaan - Kerajaan Prambonan menjadi telaga - pernikahan tidak terjadi.

Pertalian antar bagian-bagian alur tersebut merupakan hubungan sebab-akibat, sebagai penanda hubugan yang logis, yang juga disertai dengan permainan aksioma, yaitu bahwa perilaku tidak tepuji dan serakah akan mendatangkan bahaya dan keburukan. Hal tersebut muncul terutama disebabkan oleh prilaku Dewi Mayangsari yang menghias rambutnya gengan permata, serta tidak menerima nasehat ayahnya, malah melempari wajah ayahnya dengan bakul permata. Kejadian tersebut telah menimbulkan kekecewaan Mahawiku Dewi Centringmanik, sehingga tanpa disadarinya keluarlah kutukan untuk Kerajaan Prambonan.

\section{Penokohan}

Penokohan pada Sasakala TalagaWarna terdiri atas: (1) Raja Prambonan (tidak disebutkan namanya), seorang yang arif dan bijaksana, (2) Dewi Mayangsari, putri raja Prambonan, sangat cantik, jelek perangainya, (3) Layung Kumendung, anak angkat Mahawiku Dewi Centringmanik, (4) Dewi Centringmanik, seorang mahawiku, seorang pertapa yang sakti di Buana Pancatengah (5) Eyang Uja, seorang maharesi yang sering dimintai pertolongannya, (6) Dewi Gelanggading, raja Batungampar, (7) Gajah Panambur, patih kerajaan Batunagmpar, seorang panglima perang yang sangat digjaya, (8) Raden Suryakencana, putra Dewi Citrawati dari negara Kajinan, sangat sakti dan sering dimintai pertolongan, (9) Dewi Citrawati, ibunda Raden Suryakencana dari negara jin, (10) Prabu Manyir, raja Argabelah, seorang yang gagah, berani, sakti, bengis dan lalim, (11) Aria Kalasusela, patih Kerajaan Argabelah, seorang yang sakti dan bengis.
Berdasarkan peranannya dalam struktur alur, penokohan utama dalam Sasakala Talaga Warna adalah Layung Kumendung dan Dewi Mayangsari. Kedua penokohan itulah yang terlibat dalam pokok peristiwa cerita. Penokohan-penokohan lainnya berperan sebagai penokohan tambahan atau pembantu.

Adapun berdasarkan wataknya, Layung Kumendung sebagai tokoh yang memiliki tabiat baik, merupakan tokoh protagonis, sedangkan Prabu Manyir dan Patih Aria Kalasusela sebagai lawannya, merupakan tokoh antagonis.

\section{Latar/Setting}

Kejadian dalam cerita ini berlatarkan beberapa tempat, yaitu: (1) Prambonan, kerajaan yang dikutuk oleh Dewi Centringmanik menjadi telaga, (2) Buana Pancatengah, padepokan tempat belajar dan betapa Raden Layung Kumendung dan Mahawiku Dewi Centringmanik, (3) Argabelah, kerajaan yang dipimpin oleh Prabu Manyir dan patihnya Aria Kalasusela, (4) Batungampar, kerajaan yang dipimpin oleh Dewi Gelanggading dan patinya Gajah Panabur, (5) Kerajaan jin, tempat Raden Suryakencana dan Dewi Citrawati, (6) Hutan, tempat bertempur antara Gajah Panambur dengan Aria Kalasusela, (7) Talaga (talaga warna), penjelmaan dari kerajaan Prambonan yang dikutuk.

Penyebutan nama tempat tersebut tidak disertai dengan gambaran atau deskripsi konkret tentang keadaan (situasi), serta tidak pula digambarkan suasana saat peristiwa cerita berlangsung. Demikian juga latar waktu, tidak disebutkan sama sekali dan tidak tertera sepanjang jalinan cerita.

\section{Tema dan Amanat}

Tema yang tersirat dalam legenda ini adalah percintaan atau asmara yang terbingkai dalam struktur kekuasaan.

Tema lainnya yang menjiwai cerita ini adalah tema moral, yang juga sekaligus sebagai amanat cerita. Amanat seperti ini pun kerap dijumpai dalam ksah-kisah klasik: bahwa yangjujur dan baik akan selamat serta mendapatkan kebahagaiaan, serta yang perilakunya menyimpang dan nista, akan mengalami penderitaan dan siksaan. Hal tersebut di antaranya dialami oleh Dewi Mayangsari yang dikutuk oleh Dewi 
Centringmanik setelah melempar ayahnya dengan bakul permata.

Cerita ini mengandung nilai kemasyarakatan (di samping legenda sebagai salah satu genre sastra), yaitu penggambaran strata sosial yang dilestarikan dalam perjodohan.

\section{Sasakala Batununggal (Desa Cihea) Jalan Cerita}

Alur pada Sasakala Batununggal dapat diskemakan sebagai berikut: Tumenggung Nampabaya dan Tumenggung Lirbaya dengan disertai dua orang pengawalnya, Nayakerta dan Nayakerti, menempuh perjalanan panjang yang sangat melelahkan. Keduanya beristirahat di hutan dan tertidur di atas sebuah batu. Datang hujan dan banjir besar. Kedua Tumenggung tersebut hanyut terbawa banjir. Dalam tidurnya mereka bermimpi bertemu seorang lelaki. Lelaki itu menasehati agar kedua Tumenggung tersebut kembali, dan jika menemukan sebuah jejak yang besar harus diikuti karena jejak tersebut merupakan petunjuk tentang sebuah benda (pusaka) yang sangat berguna bagi raja. Lelaki tersebut kemudian menghilang kembali. Sejak peristiwa itu, batu besar tempat Tumenggung Nampabaya dan Tumenggung Lirbaya tertidur disebut Batununggal.

Laju alur dalam legenda ini sangat linear sehingga mudah untuk diikuti serta tidak menimbulkan banyak tafsir. Di samping itu, alur yang digunakan pun merupakan alur tunggal, yang tidak memiliki persimpangn atau anak alur lainnya.

\section{Penokohan}

Penokohan pada legenda Batununggal terdiri atas: (1) Nampabaya, seorang tumenggung, (2) Lirbaya, seorang tumenggung, (3) Nayakerta, seorang pengawal, (4) Nayakerti, seorang pengawal, (5) Lelaki tua, tinggi besar dan berjanggut, merupakan sosok yang hadir dan memberi nasehat dalam mimpi Nampabaya dan Lirbaya, (6) Tokoh sentral dalam cerita ini adalah Nampabaya dan Lirbaya. Kedua tokoh tersebut merupakan pusat pengisahan sehingga apapun yang dilakukannya termasuk bekas tempat tidur mereka (batu) menjadi monumental. Adapun Nayakerta, Nayakerti, dan lelaki tua, merupakan tokoh pembantu atau tokoh tambahan.

\section{Latar/Setting}

Latar atau tempat kejadian dalam cerita ini yaitu di hutan, tempat beristirahat dan tertidurnya Nampabaya dan Lirbaya. Tempat lain yang terasa yaitu sebuah area yang disebut parung, yang ada pohon pinangnya, ketika kedua tumenggung tersebut terjaga kembali dari tidurnya setelah terbawa dan dihanyutkan banjir.

Tidak ada penyebutan latar waktu dalam cerita ini, hanya suasana yang jelas tergambar sepanjang cerita, misalnya ketika dua pengawal (Nayakerta dan Nayakerti) kehilangan tuannya; tergambar sangat pilu, bahkan menangis dan berteriak-teriak. Suasana lain juga tampak ketika Nampabaya dan Lirbaya dinasehati oleh seorang lelaki tua dalam mimpinya. Kedua tumenggung tersebut sangat khidmat menyimak petuah lelaki tua tersebut.

\section{Tema dan Amanat}

Tema dalam cerita ini adalah kepatuhan dalam menjalankan tugas yang dikemas dalam bingkai petualangan atau ekspedisi. Pengemban tugas dan petualang dalam kisah ini yaitu Nampabaya dan Lirbaya yang secara bertanggung jawab menjalankan tugasnya sampai suatu hari sangat kelelahan dan beristirahat di sebuah hutan, bukan hanya kepada raja, kepatuhan kedua tumenggung ini pun tampak ketika dinasehati oleh lelaki tua dalam mimpinya, yaitu agar segera kembali ke tempat semula, serta jika dalam perjalanan kembali tersebut mendapatkan sebuah benda pusaka, maka serahkanlah kepada raja, niscaya akan semakin disayang oleh raja. Tampak sekali bahwa kedua tumenggung itu sangat setuju terhadap nasehat lelaki tua itu, dan sedikitpun tidak tersirat bahwa mereka akan melanggarnya, termasuk menyerahkan benda (pusaka) kepada raja jika menemukannya.

\section{Sasakala Pasir Asahan (Desa Cihea) Jalan Cerita}

Alur cerita Sasakala Pasir Asahan dapat diskemakan sebagai berikut : Nampabaya, Lirbaya, Nayakerta, dan Nayakerti melanjutkan perjalanan. Di jalan buntu menemukan bebatuan yang bentuknya menyerupai batu asahan. Nampabaya dan Lirbaya mengambil satu dan mematahkannya. Di dalam patahan batu tersebut terdapat permata. Pedang Nayakerta diasah dengan permata. Pedang ditebaskan ke 
paha Nayakerti. Nayakerti terluka dan mengeluarkan banyak darah. Nampabaya mengusap paha Nayakerti. Sekejap luka Nayakerti sembuh kembali.

Nampabaya, Lirbaya Nayakerta, Nayakerti dikenal sebagai orang yang tak mempan senjata tajam. Setelah pedang diasah dengan batu permata, jadi tembus. Meraka was-was. Nampabaya mengambil dan membawa pulang beberapa batu asahan. Nampabaya menyuruh membuang batu asahan sisanya ke curug (air terjun) Cihea. Mereka segera kembali ke Mataram untuk menyerahkan barang temuannya tersebut. Sultan Agung senang menerima persembahan itu. Nampaknya diangkat menjadi Dalem Cihea. Tempat ditemukannya batu berbentuk asahan dinamakan Pasir Asahan.

Alur dalam legenda ini hampir mirip dengan alur pada cerita Sasakala Batununggal (SB). Selain datar, juga tidak ada gejolak yang menimbulkan kejutan cerita, walaupun memang ada beberapa peristiwa luar biasa atau ajaib, di antaranya ketika Nayakerti ditebas pahanya dan terluka, kemudian luka itu diusap oleh Nampabaya serta seketika itu sembuh kembalai, tapi penyajian peristiwa itu dinarasikan secara verbal sekali, sehingga tidak ada teknik maupun segi intrisik cerita yang disampaikan melalui kepekatan ikonisitas.

\section{Penokohan}

Penokohan pada Sasakala Pasir Asahan terdiri atas: (1) Nampabaya, seorang tumenggung, (2) Lirbaya, seorang tumenggung, (3) Nayakerta, seorang pengawal, (4) Nayakerti, seorang pengawal, (5) Lelaki tua, tinggi besar dan berjanggut,k merupakan sosok yang hadir dan memberi nasehat dalam mimpi Nampabaya dan Lirbaya, (6) Sultan Agung, Raja Mataram.

\section{Latar/Setting}

Beberapa nama tempat yang disebutkan dan menjadi latar dalam cerita ini, antara lain: (1) Cihea, yaitu sebuah wilayah kadeleman yang dipimpin oleh Nampabaya, (2) Curug Cihea, adalah sebuah air terjun yang terletak di Cihea, tempat dibuangnya sebagian batu yang menyerupai asahan, (3) Mataram, nama sebuah kerajaan di Jawa, yang kerap menarik upeti dari kerajaan-kerajaan kecil atau kedaleman, (4) Perbukitan, sebuah kawasan yang dilalui oleh rombongan Nampabaya dan kawan-kawan, (5) Arah selatan, yaitu arah yang harus ditempuh oleh Nampabaya dan kawan-kawan dalam meneruskan perjalannnya sesuai petunjuk lelaki tua dalam mimpinya, (6) Jalan buntu, sebuah jalan sebagai tanda atau tempat ditemukannya jenis bebatuan yang menyerupai asahan serta di dalamnya mengandung batu permata.

Tidak ada penyebutan latar waktu dalam cerita ini, tetapi gambaran suasana cerita sangat jelas kentara, misalanya kegembiraan Nampabaya dan kawan-kawan ketika menemukan bebatuan seperti yang disebutkan oleh lelaki tua dalam mimpinya.

Keseluruhan suasana cerita tersebut menyatu dalam jalinan peristiwa yang intern serta sekaligus menimbulkan multi tafsir, misalnya kegembiraan raja Mataram ketika menerima persenbahan bebatuan (batu asahan), tampak gembira. Hal tersebut dapat ditafsirkan karena memang merasa bahagia memiliki bawahan yang taat dan patuh, atau bisa pula karena dia mengetahui bahwa jika batu tersebut dipatahkan, di dalamnya terdapat batu permata yang dapat dipakai untuk mengasah pedang, serta jika pedang telah diasah dengan batu permata tersebut, maka pedang itu dapat menembus menembus tubuh Nampabaya dan Kawan-kawan, yang selama ini dikenal kebal senjata tajam.

\section{Tema dan Amanat}

Tema yang termaktub dalam cerita ini adalah tentang pengabdian dan kepatuhan dala menjalankan tugas, yang dimajemukan dengan kisah petualangan atau ekspedisi. Ketaatan dan kepatuhan inilah, amanat yang tersirat dari kisah ini, apalagi biarpun hatinya was-was, Nampabaya dan kawan-kawan tetap saja dengan tulus dan tanpa berprasangka buruk menyerahkan barang temuannya tersebut. Hal itulah yang menunjukan bahwa mereka memang benar-benar loyal dan penuh dedikasi dalam mengemban sebuah misi.

\section{Sanghyang Tapak (Kp. Babakan Ds. Leuwikoja) \\ Jalan Cerita}

Alur cerita Sanghyang Tapak dapat diskemakan sebagai berikut: Eyang Haji Manggurat Datar bersama Candra Wulan, istrinya, memimpin sebuah wilayah serta memiliki pengaruh sangat kuat di masyarakat. Rakyat merasa terlindungi dan diayomi oleh kepemimpinannya. Haji Manggurat Datar 
memiliki seorang pembantu utama yaitu Eyang Demang Candra manggala. Haji Manggurat datar membuat dua tanda peninggalan, yaitu telapak kaki dan sebuah batu besar menyerupai kasur, bekas Candra Wulan melahirkan. Berkat peninggalannya tersebut Haji Manggurat datar dijuluki Sanghyang Tapak.

Alur kisah ini, seperti rentetan peristiwa yang sering diceritakan warga Desa Leuwikoja, merupakan alur sorot balik.

\section{Penokohan}

Beberapa penokohan yang menggerakan cerita Sanghyang Tapak, yaitu: 1) Haji Manggurat Datar, seorang yang arif dan bijaksana, yang mampu membawa rakyatnya menjadi makmur dan sejahtera, dijuluki sebagai Sanghyang Tapak, (2) Candra Wulan, istri Haji manggurat Datar, yang turut menjadikan daerah pimpinan Haji Manggurat Datar menjadi tentram, (3) Eyang Demang Candra Manggala, orang kepercayaan Haji Manggurat Datar berpangkat demang, (4) Rakyat, penokohan kolektif, masyarakat yang dipimpin oleh Haji Manggurat Datar.

\section{Latar/Setting}

Latar tempat sebagai arena berlangsungnya peristiwa cerita dalam legenda Sanghyang Tapak antara lain : (1) Hutan, tempat (beradanya) sebuah kawasan yang disebut Sanghyang Tapak sebagai tempat yang dianggap keramat, (2) Gunung, kawasan yang mengitari wilayah Sanghyang Tapak, jalan yang harus dilalui menuju Sanghyang Tapak, (3) Bogor, nama tempat yang dituju Haji Manggurat Datar dengan cara terbang, serta meninggalkan sebuah jejak di tempat tersebut, yaitu sebuah tapak kaki.

Tidak ada penyebutan latar waktu dalam cerita ini, sedangkan suasana cerita berlangsung dalam sebuah kedaan yang tentram, adem, dan tenang. Hal tersebut antara lain disebabkan karena Haji Manggurat Datar yang dibantu Eyang Demang Candra Manggala, memerintah dan mengelola wilayahnya dengan arif dan bijaksana, sehingga ketentraman, kemakmuran dan kesejahteraan dapat tercipta.

\section{Tema dan Amanat}

Tema dan sekaligus amanat yang diusung ini adalah pemerintahan yang adil dan makmur, dengan berlandaskan kepada sikap pemimpinnya yang arif dan bijaksana. Menghormati sesame dan menyayangi seluruh rakyatnya, merupakan, merupakan cerminan figure seorang pemimpin yang layak menjadi panutan rakyatnya, seperti tergambar dalam prilaku Haji Manggurat Dtar beserta istrinya, Candra Wulan, serta Eyang Demang Candra Manggala, seorang demang, orang kepercayaan Haji Manggurat Datar.

\section{Surya Kancana (Kec. Cikalong Wetan) Jalan Cerita}

Alur cerita Surya Kancana dapat diskemakan menjadi sebagai berikut. Raden Arya Wiratanudatar, Dalem Cikundul, merupakan keturunan kedelapan dari Prabu Siliwangi. Dia seorang pertapa dan taat beragama. Ketika menginjak dewasa dia merupakan seorang lelaki yang tamoan dan gagah. Banyak perempuan yang ingin diperistri. Dalam sebuah pertapaan dia di datangi seorang perempuan dari negeri kajinan, Indang Sukesih. Arya Wiratanudatar menikah dengan Indang Sukesih di Negara jin. Mereka mempunyai anak dua, Indang Kancana dan Surya Kancana. Kedua anaknya tersebut sangat nakal. Indang Sukesih dan Wiratanudatar kewalahan mengurus anaknya tersebut. Anaknya dibuang. Indang Kancana ke Gunung Kumbang dan Surya Kancana ke Gunung Gede.

Alur yang digunakan dalam cerita ini merupakan alur maju. Alur kisah ini sangat linear sehingga mudah diikuti, walaupun ada kemungkinan pendengar atau pembaca cerita akan mempunyai kesulitan dalam mengingat nama tokoh-tokoh, terutama tokoh-tokoh keturunan Prabu Siliwangi yang cukup banyak disebutkan dalam kisah ini.

\section{Penokohan}

Nama penokohan dalam legenda Surya Kancana adalah sebagai berikut : (1) Prabu Siliwangi, merupakan titik tolak pengisahan, sebagai leluhur dari tokoh-tokoh dalam cerita ini, (2) Mundingsari, putra Prabu Siliwangi, (3) Mundingsari Leutik, putra Mundingsari, (4) Pucuk Umum, putra Mundingsari Leutik, tinggal di Banten Girang, (4) Sunan Parunggangsa, putra Pucuk Umum, (6) Sunan Wanafsi, raja Talaga, putra sulung Sunan Parunggangsa, (7)Sunan Ciburang, putra Sunan Wanafsi, terkenal sakti, ia kebal terhadap senjata tajam dan sangat taat beribadah, (8) 
Raden Arya, putra Sunan Ciburang, seorang yang taat beragama dan seorang pertapa, (9) Arya Wiratanudatar, putra Raden Arya, Dalem Cikundul, menikah dengan putrid jin, Indang Sukesih, (10) Indang Sukesih, putri kajinan, istri Arya Wiratanudatar, (11) Indang Kancana, anak Wiratanudatar dari Indang Sukesih, sangat nakal, (12) Surya Kancana, anak Wiratanudatar dari Indang Sukesih, sangat nakal.

Tokoh yang paling banyak dikisahkan dalam legenda ini adalah Arya Wiratanudatar, sejak dia remaja dan rajin bertapa, samapai menemukan jodohnya dengan putrid jin. Oleh sebab itu, wlaupun yang diangkat menjadi bahan cerita ini adalah tokoh Surya Kancana, tetapi segala latar belakang kehidupan Arya Wiratanudatar paling menonjol dan banyak dikedepankan, karena persoalan tersebut sekaligus merupakan latar belakang kelahiran dan kehidupan Surya Kancana. Hal tersebut malah menjadi simpul yang dapat dinurut: mengapa Surya Kancana lahir? Dan turunan darimana dia? Serta mengapa pula perilakunya sangat nakal sehingga perlu diasingkan ke Guinung Gede?

\section{Latar/Setting}

Beberapa nama tempat sempat disebutkan dalam legenda ini, antara lain : (1) Pajajaran, nama sebuah kerajaan di Tatar Sunda yang dalam legenda ini rajanya bernama Prabu Siliwangi, (2) Banten Girang, tempat tinggalnya Prabu Pucuk Umum, anaknya Mundingsari Leutik, (3) Talaga, nama sebuah kerajaan kecil yang terletak di Majalengka, (4) Barat, arah mata angina sebagai arah jalan yang harus ditempuh oleh Raden Arya, (5) Sagaraherang, tempat bermukim (sementara) Raden arya, (6) Cikundul, yaitu suatu daerah administrative (kadaleman) yang terletak di wilayah Cianjur, (7) Gunung Kumbang, tempat dibuang atau diungsikannya Indang Kancana, (8) Gunung Gede, tempat dibuangnya Surya kancana.

Tidak terdapat dan tidak disebutkan latar waktu dalam cerita ini, tetapi suasana cerita jelas tergambar sepanjang Jalan Cerita. Ada suasana khusuk dan khidmat, seperti adegan bertapa, ada juga suasana jengkel, misalnya ketika Arya Wiratanudatar dan Indang Sukesih menghadapi kenakalan Surya Kancana dan Indang Kancana.

\section{Tema dan Amanat}

Tema yang diangkat dalam legenda ini yaitu tentang silsilah keturunan yang berimplikasi terhadap pemegang kekuasaan di sebuah kerajaan. Sebuah legitimasi rupanya menjadi suatu hal yang sangat penting, karena berkaitan dengan citra seseorang di masyarakat.

Tema cerita tersebut sekaligus menyiratkan amanat, bahwa jika dalam sebuah rantai ada yang berprilaku ganjil, maka ia hendaknya rela menjalani hukuman, seberat apapun, sesuai serta sebanding dengan tingkat kesalahannya, seperti diasingkannya Indang kancana dan Surya Kancana karena dianggap terlalu nakal oleh ibu-bapaknya.

\section{Kadaleman Cikadu (Kp. Cikadu, Ds. Jamali, Kec. Mande) \\ Jalan Cerita}

Alur cerita Sasakala Kadaleman Cikadu dapat diskemakan sebagai berikut: Raden Aria Natamanggala merupakan cucu Pangeran Girilaya atau cicit Sunan Wanafri Cirebon. Kesukaannya adalah mengembara dan bertapa. Ia mendapatkan petunjuk untuk pergi kea rah timur. Mengabdi di Kerajaan Mataram. Ia sempat mengganti namanya menjadi Babad Angsa, kemudian ganti lagi menjadi Babad Kinayungan.

Ia minggat dari mataram. Pergi ke kadaleman Cipamingkis. Nikah dengan putri dalem. Mendirikan kadaleman baru (Cikadu). Datang sembilan orang Bugis hendak mengambil istrinya. Terjadi pertarungan. Orang-orang Bugis tewas. Cikadu menjadi kadaleman yang besar dan makmur.

Sultan Mataram mengetahui keberadaan Kinayungan dengan kadaleman barunya. Sultan mengirimkan utusan menangkapnya. Kinayungan mengganti nama menjadi Prabu Sacakusumah. Utusan tidak menemukan Kinayungan dan kembali ke Mataram. Utusan kembalkai datang untuk menangkap Prabu Sacakusumah. Kinayungan mengganti namanya lagi menjadi Sukma Muda. Utusan tidak menemukan Prabu Scakusumah dan kembali ke Mtaram. Utusan datang lagi untuk menangkap Sukma Muda karena diyakini sebagai babad Kinayungan. Natamanggala tidak dapat mengelak. Ia datang ke Mataram dengan menunggangi tombak pusaka. Ia ternyata memiliki tali persaudaraan dengan sultan. Ia diberi gelar Natamanggala I. 


\section{Penokohan}

Tokoh atau penokohan pada cerita ini adalah : (1) Natamanggala, demang Cikadu, seorang petapa dan gemar mengembara, sering berganti nama diantaranya menjadi Babad Angsa, Babad Kinayungan, Prabu Sacakusumah, dan Sukma Muda, (2) Sunan Wanafri, buyut Natamanggala, (3) Pangeran Girilaya, kakek Natamanggala, (4) Eyang Cipamingkis, paman Natamanggala, (5) Putri dalem, istri Natamanggala, anak Eyang Cipamingkis, (6) Sultan, raja Mataram, (7) Hulubalang, utusan Sultan Mataram untuk menangkap Natamanggala, (8) Eyang Singakerta, patih Kadaleman Cikadu, (9) Eyang Singakerti, patih Kadaleman Cikadu, (10) Kyai Penghulu Muhammad Soleh, penasehat Kadaleman Cikadu, (11) Orang Bugis, berjumlah sembilan orang, buronan yang pernah mengacau di Kadaleman Cipamingkis.

\section{Latar/Setting}

Beberapa nama tempat yang disebutkan dalam cerita ini adalah: (1) Cikadu, sebuah kadaleman yang terletak di kawasan Cibalagung (Kec. Mande), (2) Cirebon, tempat asal Sunan Wanafri, (3) Kerajaan Mataram, sebuah kerajaan yang dikunjungi natamanggala berdasarkan petunjuk dalam semedinya, (4) Cipamingkis, sebuah kadaleman (sekarang Bogor) yang dipimpin oleh Eyang Cipamingkis, paman Natamanggala, (5) Gua dan Hutan, tempat mengembara dan bertapanya Natamanggala, (6) Arah timur, arah perjalanan yang harus ditempuh oleh Natamanggala berdasarkan petunjuk semedinya.

Seperti pada legenda lainnya, tidak ada penyebutan latar waktu dalam keseluruhan jalinan cerita, secara eksplisit tidak terdapat keterangan waktu, baik penyebutan nama hari, bulan, maupun tahun, juga tidak disebutkan terjadinya peristiwa cerita yang merujuk pada keterangan waktu seperti pagi, siang, malam, dan lainnya.

Suasana cerita yang tergambar dalam legenda ini cukup beragam, ada suasana khusuk dan khidmat, ada suasana tertantang dan penasaran, ada juga suasana tegang dan waswas, yaitu ketika Natamanggala dicari dan hendak ditangkap oleh hulubalang utusan Sultan, serta ada suasana senang dan gembira, yaitu ketika diketahui bahwa silsilah
Natamanggala dan Sultan Mataram ternyata memiliki pertalian persaudaraan.

\section{Tema dan Amanat}

Pokok cerita yang menjiwai seluruh peristiwa dalam leginda ini adalah berpadunya antara jiwa petualang dan petapa dengan tekad untuk mengabdi serta keteguhan hati untuk mempertahankan dan menjaga harga diri.

\section{Eyang Paninggaran (Kp. Gunung Masigit, Ds. Jamali) \\ Jalan Cerita}

Alur yang digunakan dalam cerita ini merupakan alur maju. Alur cerita legenda ini dapat diskemakan menjadi sebagai berikut: seorang pemuda berguru kepada Syeh Maulana Syarif Hidayatulloh. Dia sangat rajin, tabah, penuh rasa tanggung jawab, serta sangat taat. Dia sangat disayang gurunya. Dia memiliki hobi berburu sehingga disebut Eyang Paninggaran. Gurunya memanggil dan menasehatinya agar dia segera mengamalkan ilmunya. Dia pergi ke arah barat dengan berjalan kaki. Di sepanjang perjalanan dia terus berdakwah. Bertemu dengan Ariawiratanudatar, Dalem Cikundul. Dia ikut ke cikundul untuk mengabdikan diri. Dia disuruh mencari area baru untuk dijadikan kadaleman. Sampai di Pasir. Pasir tersebut dibukanya dijadikan perkampungan. Berdatanglah orang yang hendak mengaji dan bermukim. Usia Eyang Paninggaran semakin lanjut. Dia meninggal. Dimakamkan di daerah Pasir.

\section{Penokohan}

Nama tokoh-tokoh yang disebut dalam legenda ini adalah sebagai berikut: (1) Syeh Maulana Syarif Hidatatulloh, guru Eyang Paninggaran, (2) Eyang Paninggaran, seorang yang menaruh minat tinggi tarhadap bidang agama, pendiri pesantren,

Ariawiratanudatar, Dalem Cikundul.

Eyang Paninggaran merupakan tokoh yang paling banyak disorot dan selalu hadir dalam setiap adegan cerita. Oleh sebab itu, dia merupakan tokoh utama, yang selalu menghidupkan peristiwa cerita. Adapun tokoh lainnya, merupakan tokoh tambahan atau tokoh hiburan.

\section{Latar/Setting}

Beberapa tempat yang menjadi latar terjadinya dalam peristiwa dalam kisah ini 
adalah: (1) Cikundul, nama sebuah kadaleman yang dipimpin oleh Ariawiratanudatar, (2) Pasir, nama sebuah daerah yang kemudian dijadikan perkampungan oleh Eyang Paninggaran, (3) Pondok Pesantren, tempat menimba ilmu yang didirikan oleh Eyang Paninggaran, (4) Hutan, wilayah yang harus dilalui oleh Eyang Paninggaran untuk mencari daerah baru untuk dijadikan padaleman, (5) Arah barat, arah wilayah yang harus dicari oleh Eyang Paninggaran untuk penyebaran agama Islam.

Tidak terdapat keterangan waktu untuk menunjukan saat-saat berlangsungnya peristiwa dalam cerita, sedangkan suasana yang tergambar di antaranya ada suasana khusuk dan taat, yaitu ketika Eyang Paninggaran menuntut Ilmu kepada Syeh Maulana Syarif Hidayatulloh, suasana tertantang dan petualang, yaitu ketika Eyang Paninggaran diharuskan mencari daerah baru untuk dijadikan kadaleman, serta suasana senang dan meriah, yaitu ketika perkampungan yang telah dibuka oleh Eyang Paninggaran banyak dikunjungi orang untuk mengaji dan bermukim.

\section{Tema dan Amanat}

Pokok masalah yang diangkat dan menjiwai legenda ini adalah spirit mencari ilmu yang disandingkan dengan keikhlasan hati untuk mengabdi. Tersirat pesan bahwa mencari ilmu memang harus dijalani dengan sepenuh hati dan jangan tanggung-tanggung, serta ilmu yang sudah diperoleh hendaknya diamalkan agar bermanfaat bagi kemaslahatan umat.

\section{Sasakala Pasirdalem dan Irigasi Ciaripin (kec. Kadupandak) \\ Jalan Cerita}

Alur cerita kisah ini bersifat linear, mudah diikuti serta tidak banyak mengandung simpangan. Peristiwa-peristiwa cerita dihadirkan secara runut dan beruntun. Alur cerita Sasakala Pasirdalem dan Irigasi Ciaripin dapat diskemakan sebagai berikut: masyarakat Peuntas atau Pasirdalem berinisiatif membangun saluran irigasi yang dinamai Ciaripin. Pembuatan irigasi tersebut dilaporkan kepada Dalem Cianjur, R.A.A. Wiranatakusumah XII. Dalem mengunjungi Parakantugu. Masyarakat menyambutnya dengan membangun tempat pertemuan setengah resmi di atas bukit. Dari tempat tersebut terlihat hamparan pemandangan di sekelilingnya.
Dalem datang disertai pejabat lainnya. Pertemuan berlangsung tujuh hari tujuh malam. Kunjungan Dalem membuat bahagia dan bangga warga masyarakat. Saluran irigasi itu masih berfungsi sampai sekarang. Nama Pasirdalem diabadikan menjadi nama sebuah desa pemekaran.

\section{Penokohan}

Tokoh cerita yang terlibat dalam peristiwa legenda Sasakala Pasirdalem dan Irigasi Ciaripin, adalah sebagai berikut: (1) Suramanggala, kepala desa Parakantugu yang diangkat oleh pemerintah kolonial Belanda, (2) R.A.A. Wiranatakusumah XII, Dalem Cianjur ke-12, yang meresmikan irigasi Ciaripin, (3) Bupati, wedana, camat, pamong desa, merupakan rombongan yang menyertai kedatangan Dalem ke Parakantugu, yang juga disertai warga masyarakat.

Hanya ada dua nama orang yang disebutkan dalam legenda ini, yaitu Wiranatakusumah XII dan Suramanggala, sedangkan bupati, wedana, camat, dan yang lainnya merupakan nama jabatan. Dari namanama tersebut pun tidak ada yang dominan dikisahkan, tetapi hanpir semuanya memiliki peranan yang merata. Hal tersebut dapat dimengerti mengingat legenda ini menceritakan tentang asal-muasal suatu tempat, bukan penamaan atau pemberian gelar kepada seseorang.

\section{Latar/Setting}

Beberapa nama tempat yang menjadi latar terjadinya peristiwa dalam legenda ini yaitu: (1) Parakantugu, sebuah desa yang dipimpin oleh Suramanggala, (2) Peuntas, tempat perkampungan yang terletak di sebelah seberang, disebut juga Pasirdalem, (3) Pasirdalem, nama sebuah desa hasil pemekaran, dahulunya disebut juga Peuntas, (4) Ciaripin, nama saluran irigasi yang dibangun secara swadaya oleh masayarakat Parakantugu, (5) Cianjur, pernah menjadi nama kadaleman, kemudian manjadi nama kabupaten, (6) Kali Cibuni, kali yang mengitari beberapa perkampungan dan pesawahan, (7) Gunung Brengbreng, batas antara Kec. Kadupandak dengan Kec. Sindangbarang, pemandangan di sebelah selatan yang dapat dilihat dari Bale Macangkrama. 
Latar waktu yang tersurat dalam cerita ini yaitu tahun 1912-1920. angka tersebut menunjukan masa pemerintahan Desa Parakantugu yang dipimpin oleh Suramanggala.

Adapun suasana yang tergambar dalam cerita ini adalah rasa senang dan gembira, terutama terlihat ketika Desa Parakantugu dikunjungi Dalem Cianjur beserta rombongan. Selain itu, juga ada suasana kebersamaan dan rasa gotong royong, yaitu ketika warga Peuntas membangun saluran irigasi Ciaripin.

\section{Tema dan Amanat}

Tema dan amanat yang terkandung dalam legenda ini adalah tentang kebersamaan hidup dan gotong royong. Hal tersebut tercermin dari perilaku kolektif masyarakat Peuntas atau Pasirdalem yang secara bersama-sama dan swadaya membangun saluran irigasi. Hal itulah di antaranya, benang merah yang dapat ditarik dari amanat legenda Sasakala Pasidalem dan Irigasi Ciaripin.

\section{SIMPULAN}

Dari pembahasan di atas dapat ditarik beberapa simpulan, di antaranya: (1) sastra lisan Sunda merupakan titik awal dari perkembangan adanya sastra Sunda secara tertulis. Sastra lisan dapat digunakan untuk memperkaya khasanah kesusasteraan Sunda bahkan Indonesia. Sastra lisan dapat mengisi kekosongan yang terjadi bila para pengarang membutuhkan variasi, atau dikatakan sebagai penunjang sastra tertulis; (2) sastra lisan di Kabupaten Cianjur itu memiliki fungsi sebagai alat untuk: mewariskan tata cara hidup, adat istiadat dan kebiasaan sehari-hari, mewariskan kepercayaan, menyampaikan pendidikan, baik pendidikan secara lahir (berupa ilmu pengetahuan) maupun pendidikan batin, moral, etika, dan agama, menyampaikan asal-usul kejadian dan hal-hal yang mengandung berita atau sejarah, hiburan, mengisi waktu senggang, baik waktu yang terluang diantara pekerjaan penduduk seharihari, maupun waktu yang sengaja disediakan dalam acara tertentu.

\section{PUSTAKA RUJUKAN}

Fokkema, D.W. dan Elrud Kunne-Ibsch. 1977. Theories of Literature in the Twentieth Century. Lonton: G. Hurst \& Co.

Hawkes, Terence. 1978. Structuralism and Semiotics. London: Mathuen \& Co Ltd.

\section{UCAPAN TERIMA KASIH}

Terima kasih kami sampaikan kepada penyunting jurnal atas dimuatnya tulisan ini. Semoga bermanfaat bagi pengembangan keilmuan khususnya khasanah sastra. 